\title{
A MAGYARORSZÁGON ÉLŐ KÜLFÖLDIEK TERÜLETI ELHELYEZKEDÉSE
}

\author{
(Location of Foreign Citizen in Hungary)
}

\section{KINCSES ÁRON}

Kulcsszavak:

nemzetközi vándorlás területi különbségek elérhetöség

A hazánkban éló külföldi állampolgárok területi elhelyezkedése és lakóhelyválasztásuk okai eltérnek a magyar népességtöl. Erös koncentrációjuk fokozza a migráció területi hatásait. A jövedelemkülönbségek mellett a lakóhely helyzetének, központi vagy éppen határ menti fekvésének is fontos szerep jut a külföldi állampolgárságú népesség kistérségi eloszlásának magyarázatában, mellyel a tanulmány elsö fele foglalkozik. A következö részben a migrációs hálózatokat vizsgáljuk, és az elérhetöségi modellek segitségével szemléltetjük, hogyan láthatják a külföldiek Magyarország kistérségeit, mint potenciális letelepedési célpontokat.

\section{Bevezetés}

A célunk, hogy bemutassuk a Magyarországon tartózkodó külföldi állampolgárok és bevándorlók területi jellemzőit, lakóhely választásuk lehetséges okait és eltéréseit a magyar népességhez képest. Ennek érdekében létszámukat, korösszetételüket, foglakozásukat és iskolai végzettségüket vizsgáltuk kistérségi szinten. Ezt a területi szintet azért választottuk, mert a célkitüzéseinkhez elegendỏen differenciált vizsgálatot tesz lehetővé, de még kezelhető az analízisbe bevont részegységek száma. A külföldiek területi vizsgálatát azért tartjuk fontosnak, mert a lakónépességtỏl eltérö preferenciák alapján választanak maguknak lakóhelyet. Egyes térségek iránt alacsony az érdeklődésük, míg máshol jobban koncentrálódnak. A külföldiek aránya a kilencvenes évektöl folyamatosan növekszik hazánkban (a külföldi születésú embereké a honositásoknak köszönhetöen még ennél is dinamikusabban), így növekvó országos hatásukat is felülmúlja az általuk preferált térségekben a befolyásuk. Véleményünk szerint a külföldiek eloszlásában a szakirodalom által meghatározott legfóbb mikrogazdasági motiváló tényező, a jövedelmek területi különbségei (HattonWilliamson 2005) mellett fontos szerep jut Budapestnek, mint jelentős migrációs centrumterületnek, a határ menti területeknek, a küldő országok közelsége miatt, valamint a már itt letelepedettek által a potenciális migránsoknak nyújtott informális információknak (migrációs hálózatok). Ezt a fenti három hatást szándékozzuk részletesebben vizsgálni. Hipotézisünk szerint a fơváros környékén, valamint az ukrán, román és szerb-montenegrói határ menti kistérségekben nagyobb a külföldiek koncentrációja, mint azt az adott területen élök átlagos jövedelmeiböl következtetni lehetne. A migrációs hálózatok léte (Massey-Taylor 2004) azt eredményezheti, 
hogy állampolgárságok szerinti bontásban erős pozitív kapcsolat lehet a már letelepedett és az érkező külföldiek kistérségi eloszlásában.

Magyarországon a nyolcvanas évektől kezdődően a lakónépesség száma folyamatosan csökken. Belátható időn belül valószínủleg hazánkban csak a nemzetközi migráció képes a népességfogyást mérsékelni (Hablicsek 2003). A nemzetközi vándorlásnak közvetlen demográfiai pótló és közvetett fiatalító hatása is van. A rendszerváltás óta hazánk nemzetközi vándorlási többlettel rendelkezik. Azaz, több külföldi érkezik hazánkba, mint ahány honfitársunk elhagyja azt. A külföldiek hatása egyre nagyobb Magyarországon. Míg 30-40 ezer före tehető az éves természetes fogyás, addig 10-20 ezer fös éves, pozitív migrációs egyenleg jellemzi Magyarországot. 2007. január 1-jén 166030 külföldi állampolgár tartózkodott huzamosan hazánkban (a lakónépesség mintegy 1,6\%-a), akik potenciális letelepedőkként foghatók fel. A fenti abszolút szám az egy évnél hosszabb tartózkodási, letelepedési, bevándorlási engedélyeseket takarja, a turisták, rövid távú tartózkodók, diplomaták és menekültek adatai nem tartoznak az állományhoz. A külföldiek vizsgálatánál átfogóbb elemzést tesz lehetővé a külföldön születettek számbavétele, mely magában foglalja többek között az előző csoportosításból kimaradt magyar állampolgárságot szerzöket is (1993 és 2006 között mintegy 107 ezer fö). Az 1993-2006-os időszakra vonatkozóan a bevándorlók 43\%-a vált magyar állampolgárrá. A külföldön születettek aránya így természetesen magasabb, mint a külföldieké, a lakosság 3,6\%-a, ami a bevándorláson kívül a honosításoknak, visszahonosításoknak és a menekültek, menedékesek befogadásának köszönhetö.

Elmondható tehát, hogy a hazai népesség egy részének helyét külföldiek veszik át, magukkal hozva saját „,személyes tereiket”, szokásaikat, eltérő demográfiai összetételüket. A migrációnak így gazdasági, társadalmi, demográfiai hatásai is vannak Magyarországra nézve. Az országos hatásokat jelentősen felülmúlják a területi hatások. A nemzetközi vándorok önálló döntésük alapján változtatják meg a lakóhelyüket, mely választásra az általuk felmért külső és belső tényezők, a vonzó és taszító hatások meghatározó szereppel bírnak (Rédei 2007).

Hipotézisünk szerint a külföldiek lakóhely választását befolyásolják a lokális kereseti lehetôségek, de emellett a határ menti kistérségeket is elönyben részesítik. Budapest központi térségnek tekinthető a külföldi születésü lakosság körében. Továbbá fontos szerepe van a bevándorlók lakóhelyválasztásában a szomszédsági kapcsolatoknak. A szomszédos országok állampolgárai a saját küldő országukkal szomszédos kistérségekben nagyobb arányban vannak jelen. Véleményünk szerint az állampolgársági kapcsolatok a határ menti területeken kívül az egész országban tetten érhetők. Oda vándorolnak nagyobb arányban külföldi állampolgárok, ahol jelentősebb számú letelepedett honfitársuk van, információt és egyéb segítséget nyújtva az újonnan érkezők számára. 


\section{A külföldiek és a kistérségi átlagjövedelmek területi kapcsolata}

A külföldiek magyarországi elhelyezkedésének a szakirodalom által megfogalmazott legfőbb oka a jobb életkörülmények biztosítása (Illés-Lukács 2002), azaz az adott helyen való letelepedést gyakran gazdasági okokra lehet visszavezetni. Így az egy före jutó személyi jövedelemadó alap függvényében vizsgáltuk az 1000 lakosra jutó külföldiek arányát. Kistérségi szinten készítettük az ábrát a 2006-os adatok alapján (1. ábra). Megjegyzendő, hogy 1990-től a ponteloszlás alakja nagyon hasonló minden évben. Egyedüli eltérés, hogy időben az $X$ tengely pozitív irányába tolódik el az ábra, a növekvő kereseteknek köszönhetően. Azokban a kistérségekben, ahol magasabbak a keresetek, általában magasabb az 1000 lakosra jutó külfö̈ldiek száma, ahol gyengébbek, ott kevesebb a külföldi is.

\section{1. ÁBRA}

Az 1000 lakosra jutó külföldiek száma az átlagos adóalap függvényében kistérségenként, 2006

(Foreign Citizens per Thousand Population Plotted Against Average of Taxable Income by Subregions, 2006)

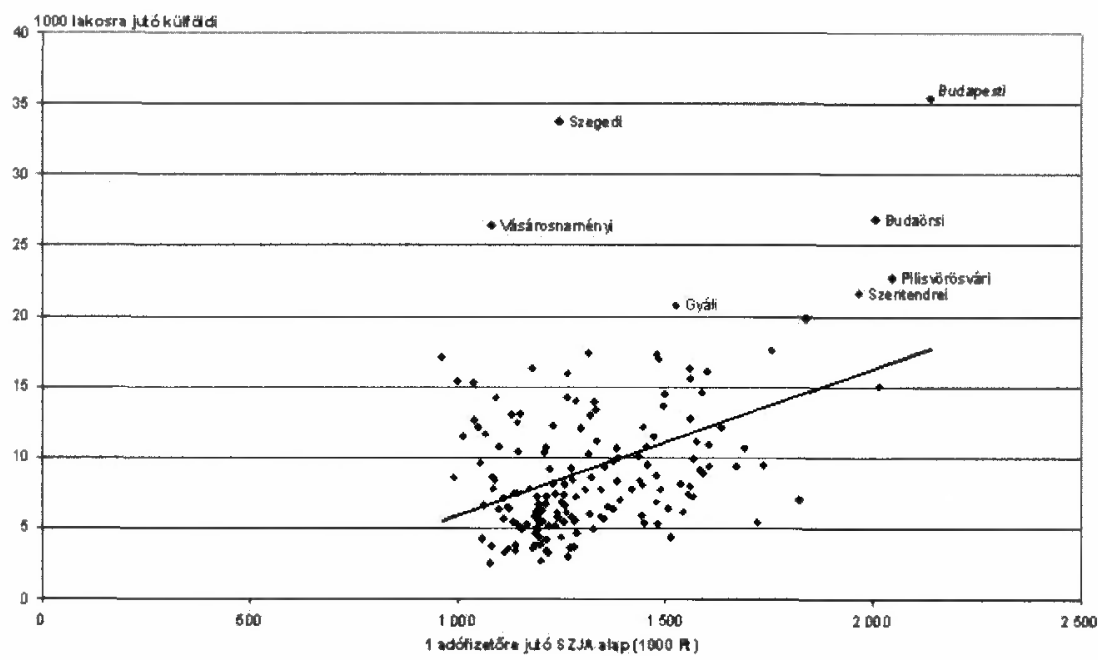

Forrás: Saját szerkesztés.

Azonban ez nem egy összes kistérségre érvényes lineáris összefüggés. Jelentős eltérések vannak ettől a trendtől. A pontosabb analízis érdekében a legkisebb négyzetek módszerével lineáris trendet illesztettünk a ponteloszlásra, majd a 2. ábrán a trendtől való relatív eltéréseket ábrázoltuk. 


\section{2. ÁBRA}

Relativ eltérések, 2006

(Relative Differences, 2006)

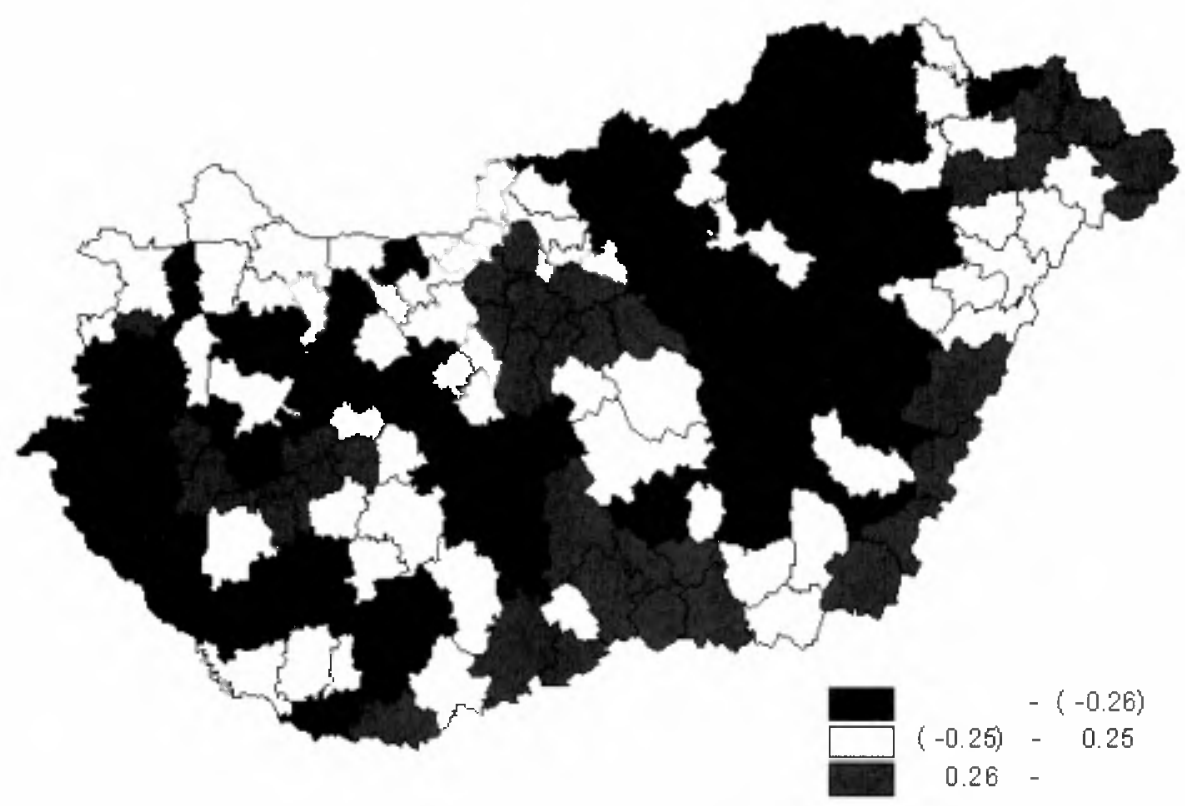

Forrás: Saját szerkesztés.

A pozitív eltérések a jövedelmek alapján elörejelzettnél arányaiban nagyobb külföldi népességet jelentenek, míg a negatív eltérések kisebbet. Ezzel igazolható, hogy a jövedelem-különbségek mellett a kistérségek helyzete, központi vagy éppen határ menti jellege befolyásolja a külföldiek területi elhelyezkedését.

Öt térség emelkedik ki pozitív értelemben az átlagból. Elsőként a Zalaszentgróti, Keszthely-hévízi, Fonyódi, Lengyeltóti, Balatonföldvári, Balatonfüredi, Siófoki kistérségek jellemezte Balaton vidéke. Másodikként a Budapesti, Szentendrei, Pilisvörösvári, Budaörsi, Ráckevei, Gyáli, Veresegyházi, Váci, Gödöllői kistérségek alkotta Budapest vonzáskörzete. Harmadikként a Nyíregyházai, Baktalórántházai, Kisvárdai, Vásárosnaményi, Fehérgyarmati ukrán határ mente. Negyedikként a Csengeri, Berettyóújfalui, Sarkadi, Gyulai, Mezőkovácsházai kistérségek jellemezte román határ mente, és végül a Siklósi, Bajai, Bácsalmási, Szegedi, Mórahalomi, Kiskunhalasi, Kiskunmajsai, Kisteleki, Kiskőrösi szerb-montenegrói határ mente. A következő részben ezeket a térségeket fogom részletesen vizsgálni. 


\section{A külföldiek által letelepedésre preferált térségek vizsgálata}

Az öt kiemelt térség Magyarország kistérségeinek a negyedét fedi le, ahol a külföldiek 65-75\%-a összpontosul, azaz nagyon magas a koncentrációjuk. A Balaton vidéke inkább természetföldrajzi, turisztikai értékeinek köszönheti a külföldiek magasabb érdeklődését. Budapest vonzáskörzete egyértelmủen centrum tulajdonságokkal rendelkezik. A határ menti három elkülönített kistérség-csoport pedig inkább kapu értelemben viselkedik, mint elválasztó határként a külföldi állampolgárok felé.

\section{Budapest és vonzáskörzete}

Az itt lakó külföldiek állampolgársága nagyon változatos, mintegy 158 ország állampolgárai élnek ebben a térségben. Jelentős számban vannak itt az EU15 országokból, Szlovákiából, Törökországból, Kínából, Vietnámból, Szerbiából és Montenegróból, Ukrajnából, Oroszországból, Szíriából, de leginkább Románia magaslik ki (37 ezer fơvel). A hazánkban tartózkodó román állampolgárok fele e térségben él. A külföldiek közel 80\%-a 20-59 éves. A 18 évnél idősebbek majdnem negyede felsőfokú végzettségủ, és közel $60 \%$ a középfokú végzettségüek aránya. Azaz átlagosan magasabb iskolai végzettségekkel és nagyobb gazdasági aktivitással rendelkeznek az itt élő magyar lakosságnál. Az EU15 tagállamok és a nem európai országok itt élö állampolgárainak majdnem fele felsőfokú végzettségủ. Az itt élő 18 éven felüli külföldek 16\%-a diák, 20\%-a nyugdỉjas, munkanélküli, illetve háztartásbeli. Többségük ukrán, vietnámi, román, orosz és kínai állampolgár. A fennmaradó mintegy $64 \%$ dolgozik, ami a lakónépesség országos arányainak másfélszerese. Nagyon változatos a foglalkozások szerinti megoszlás (3. ábra).

A gazdasági szervezet vezetői között kínaiak, vietnámiak, EU15 országok, ukránok, oroszok, románok, szerb-montenegróiak is jelentős számban fordulnak elő. A kereskedelmi és vendéglátó-ipari foglalkozások esetén a kínai, román és vietnámi állampolgárok jelenléte domináns. A könnyủipari foglalkozások 78\%-át Románia állampolgárai uralják, majd Mongólia és Ukrajna a sorrend. A vas- és fémipari foglalkozások esetén a külföldiek közel 80\%-a szintén romániai. Az egyszerủ szolgáltatási jellegü foglalkozásokat végzők is a román és ukrán állampolgárok közül kerülnek ki.

Ezt a területet a sok diák, magas gazdasági aktivitás, sokféle foglalkozási föcsoportban tevékenykedö kủlfoöldi jellemzi, mely pozitívan hat a térségre, hiszen a migráció előnyei fokozódnak, ha nagyobb a választék. Budapest egyértelmúen centrumterületnek tekinthetö a nemzetközi vándorlás vonatkozásában, hiszen nemcsak a környezỏ országok állampolgárai tekintik célpontnak, hanem más földrészröl érkezők is. A Magyarországon tartózkodó nem európai állampolgárok közel $80 \%$-a ebben a térségben él. Azaz fỏvárosunk (ha szerényebb értékekkel is, mint a nagy befogadó országok nagyvárosai) globális migrációs célponttá vált. A világban megfigyelhető trendekkel összhangban, Magyarországon is a nagyvárosi térségben kon- 
Kincses Áron : A Magyarországon élö külföldiek területi elhelyezkedése.

Tér és Társadalom 23. évf. 2009/1. 119-131. p.

centrálódnak leginkább a migránsok, a tulajdonságaikban megfigyelhető erős diverzifikáció mellett. A térség külföldi állampolgárainak száma dinamikusan növekszik (1. táblázat).

\section{3. ÁBRA}

Budapest vonzáskörzetében élö 18 éven felüli külföldiek foglalkozása (Foreigners Aged over 18 by Occupation in Budapest and the Environs of the City)

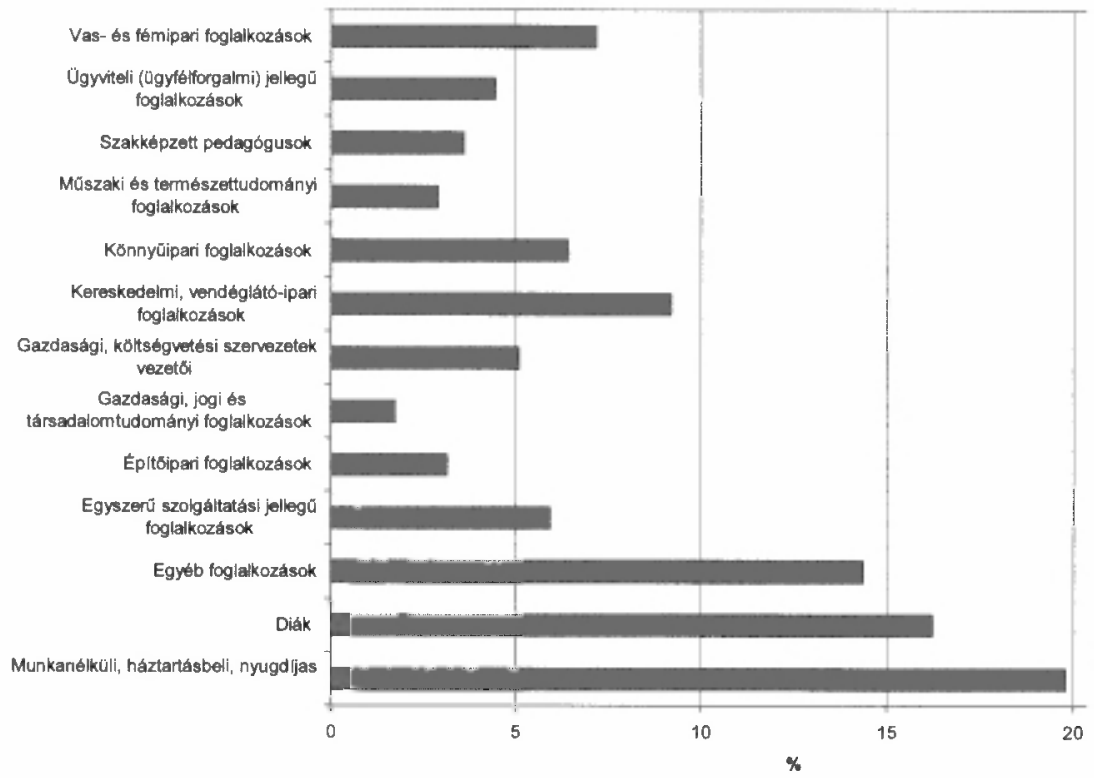

Forrás: Saját számítás.

\section{TÁBLÁZAT}

A centrumterületek külföldi lakosságának növekedési üteme, 2002-2006 (\%) (Growth Rate of Foreign Population of Centre Fields, 2002-2006, \%)

\begin{tabular}{lrrrrr}
\hline Kistérség & 2002 & 2003 & 2004 & 2005 & 2006 \\
\hline Budaörsi & 10,81 & 3,13 & 10,00 & 20,37 & 17,35 \\
Budapest & 5,61 & $-0,73$ & 5,54 & 12,01 & 16,85 \\
Gödöllöi & 11,45 & $-0,55$ & 5,41 & 19,41 & 11,81 \\
Gyáli & 12,13 & 4,16 & 13,98 & 29,39 & 19,93 \\
Pilisvörösvári & 9,24 & 2,53 & 13,30 & 21,23 & 12,77 \\
Ráckevei & 8,32 & 3,28 & 10,83 & 22,66 & 15,80 \\
Szentendrei & 9,25 & 1,45 & 6,52 & 19,91 & 13,25 \\
Váci & 8,45 & 0,83 & 9,02 & 23,54 & 13,93 \\
Veresegyházi & 22,48 & 3,01 & 6,25 & 21,03 & 21,82 \\
Összesen & 6,46 & $-0,20$ & 6,28 & 13,83 & 16,57 \\
\hline
\end{tabular}

Forrás: KSH. 
Fontos megjegyezni, hogy a centrumtérség szomszédságában lévő kistérségek is - bár nem ilyen dinamikus, de - jelentős külföldi népességnövekedést könyvelhetnek el.

\section{Határ menti térségek}

A határ menti kistérségek eltérő gazdasági karakterisztikájú tảjakat kötnek össze. Ezek közötti kapocsként, mintegy kapu szerepkörrel rendelkeznek. A román, ukrán, szerb határ menti területeken a határ nem elválasztó elem, sokkal inkább kontaktuszóna. Az itt élő külföldieknek a határmentiség hordoz többletértéket, feltehetően az otthon maradt családtagokkal így egyszerübb a személyes kapcsolattartás. Ezek az emberek kis távolságokra költöznek el előző lakóhelyüktöl. Legföképpen a határ túloldalán lévő városokból a határ innensỏ oldalán lévő kistérség-központokba költözés a jellemző.

Az ukrản határ közelében lévő öt kistérség mintegy öt és félezer fös külföldi lakosságának nem meglepő módon közel 70\%-a ukrán, 18\%-a román. Majdnem 70\%-uk aktív korú. A 18 év felettiek 48\%-a inaktív (diák, nyugdíjas, munkanélküli, háztartásbeli), 6\%-uk szakképzett pedagógus, majd ugyanennyien üznek vas- és fémipari foglalkozást, 5\%-uknak kereskedelmi, vendéglátó-ipari foglalkozása van, 4\%-uk pedig a könnyüiparban dolgozik.

A román határ közelében lévő kistérség-csoportban a nem magyar állampolgárok száma (2500 fö) elmarad a többi csoport számaitól. Az itt élö külföldiek négyötöde román állampolgár. Az aktív korúak aránya közelítőleg megegyezik az ukrán határ menti értékkel. Az iskolai végzettségek szerényebbek a külföldiek országos átlagánál. A 18 év feletti inaktívak aránya közel $50 \%$. A foglalkoztatottakra leginkább a vas- és fémipari, illetve könnyüipari foglalkozások a jellemzőek.

A szerb-montenegrói határ mentén élő 11442 külföldinek a fele a határ túloldaláról érkezett. Jelentős még az ukrán, román, horvát, bosnyák és német állampolgárok száma. Az itt élö külföldiek háromnegyede 20 és 59 év közötti. A 18 év felettiek 15\%-a diák, 27\%-a nyugdíjas vagy munkanélküli. Így a külfoóldiek 58\%-a dolgozik. Ezek között az aktív emberek között nagy számban találunk egyszerủ szolgáltatás jellegü foglalkozásokat (az összes külföldi 7\%-a), kereskedelmi és vendéglátó-ipari foglalkozásokat (7\%), ügyviteli jellegü (6\%), valamint vas- és fémipari foglalkozásokat (6\%).

Fontos megjegyezni, hogy a Tatabánya-Györ tengely esetében a fentiekhez hasonló magas aránya van a szlovák állampolgároknak is, azonban ezek a magas arányok a jövedelmek magas voltával magyarázhatóak.

\section{Balatoni térség}

A Balaton környékén az EU15 országból érkezők telepednek le nagyobb számban. A német állampolgárok aránya $50 \%$. Jelentős még az osztrákok, és a hollandok száma is. Az itt élök 40\%-a 60 év feletti, további 20\%-ot tesznek ki az 50-59 éves 
Kincses Áron : A Magyarországon élö külföldiek területi elhelyezkedése.

Tér és Társadalom 23. évf. 2009/1. 119-131. p.

korosztályba tartozók. Elmondható, hogy föként a nyugdíjasok telepednek le a Balaton környékén (Michalkó-Illés 2003). Ugyanakkor a 18 év felettiek 7\%-a a turizmusra épülö kereskedelmi és vendéglátó-ipari foglalkozással rendelkezik, ök föleg román és szerb-montenegrói állampolgárok.

Összefoglalva, a jövedelmek kistérségek szerinti eloszlása nem magyarázza teljesen a külföldiek területi arányait. Fontos szerepe van az érkezők szemében a gazdasági értékek mellett a lakóhely helyzetének is. Budapest környékét, mint dinamikus centrumtérséget, széles állampolgársági, foglalkozások szerinti megoszlás jellemzi. Sok az aktív korú és a magas iskolai végzettségủ a külföldiek között. Azaz a képzett, magasan kvalifikált munkaeröt ez a centrum nagyobb távolságokról is képes toborozni (Rédei 2002). A határ menti térségek esetén a magasabb iskolai végzettségek, az aktív korúak és foglalkoztatottak aránya kisebb a centrum területekénél, de a hazai átlagnál mindenképpen magasabb. Itt az állampolgárság és foglalkozási föcsoportok szerint is erősen koncentrálódik a külfö̈ldi népesség. Felmerül a kérdés, hogy mennyire jellemző a határ-centrum térségek közötti vándorlás. Azt lehet mondani, hogy a külföldiek belföldi vánđorlásának mintegy $60 \%$-a kistérségen belül realizálódik, így a hazánkba érkezőkre a letelepedésük után inkább csak a kis távolságú vándorlások jellemzőek. 2006-ban 13825 külföldi állampolgár vett részt a belföldi vándormozgalomban, ebböl 8206 kistérségen belül (ebböl 3448 fö Budapesten belül) váltott lakóhelyet. Ez némileg a teljes népesség lakóhely-változtatási arányai alatt van. Egyedül Budapest és a vonzáskörzetéhez tartozó kistérségek közötti vándorlás jelentősebb. Utóbbiakból 363 külföldi költözött Budapestre, míg fordítva 551 fö. Azt mondhatjuk, hogy a külföldiek az érkezésükkori letelepedési helyüket nem változtatják jelentős mértékben nagyobb távolságú költözésekkel. Azaz a letelepedett külföldiek más-más preferencia alapján választanak lakóhelyet, mely után inkább csak kistérségeken belüli mozognak. A fenti centrum-határ kistérség-csoportok között nincs intenzív áramlás. A vizsgált térségek különböző elkülöníthetö külföldi preferenciái is felhívják a figyelmet a migrációs stratégiák finom területi hangolásának igényére, a migráció szubszidiaritásának fontosságára.

\section{Migrációs hálózatok}

A migrációs hálózatok elmélete szerint (Sik 1999) a beilleszkedés az új környezetbe ott valósul meg sikeresen, ahol korábbi családi, baráti kapcsolatok ezt segítik. A küldő területek nyomása és a már letelepültek által lakott régiók között donori viszony formálódik. Így a jövedelemkülönbségek, a célterületek helyzete mellett ezek a kapcsolatok befolyásolhatják a vándorlások irányát. Ezt a kapcsolatot vizsgáljuk a tanulmány ezen fejezetében részletesebben. 


\section{Aramlási és állományi adatok közötti kapcsolat}

Megfigyelhető az állampolgársági vizsgálatok esetén az állományi és az áramlási adatok között meghúzódó erős kapcsolat kistérségi szinten. Azaz az újonnan érkezők a már meglévő struktúra szerint oszlanak meg. Ennek vizsgálatára a korrelációs együtthatót használtuk. Képletünkben az $x$ (adott év elött letelepedettek) és az $y$ (az adott évben bevándorlók) korrelációja:

$$
\operatorname{Corr}(x, y)=\frac{\sum_{i=1}^{N}\left(x_{i}-\bar{x}\right)\left(y_{i}-\bar{y}\right)}{\sqrt{\sum_{i}\left(x_{i}-\bar{x}\right)^{2} \sum_{i}\left(y_{i}-\bar{y}\right)^{2}}},
$$

ahol az i index a kistérségek szerinti adatokat jelöli.

A két adatsor közötti korrelációs együttható értéke 0,85 és 0,99 között mozog (2. táblázat).

\section{TÁBLÁZAT}

Korrelációs együtthatók, 2003-2006

(Correlation Coefficients, 2003-2006)

\begin{tabular}{lcccc}
\hline Állampolgárság & 2003 & 2004 & 2005 & 2006 \\
\hline $\begin{array}{l}\text { ukrán } \\
\text { szerb monte- }\end{array}$ & 0,85 & 0,94 & 0,95 & 0,98 \\
$\begin{array}{l}\text { negrói (jugo- } \\
\text { szláv) }\end{array}$ & 0,86 & 0,94 & 0,99 & 0,98 \\
román & 0,99 & 0,99 & 0,99 & 0,99 \\
\hline
\end{tabular}

Forrás: Saját számítás.

Ez azt jelenti, hogy nagyon erỏs, szoros viszony van a két változó között. Ebből a determinációs együttható $\left(\mathrm{r}^{2}\right)$ értéke: $\mathrm{H}=0,72-0,98$ között van. Így a Magyarországon tartózkodó külföldiek száma adott év december 31-én 72-98\%-ban magyarázza a következö évben érkezők területi szóródását, amiböl arra lehet következtetni, hogy a bevándorlók nagy százalékban végleges letelepedők lesznek. Ez a magyarázó erő határozott növekedést mutat, ami az egyre megalapozottabb döntésekkel és hazánk migrációs stratégiában betöltött csökkenö szerepével, a kibővülö kapcsolati hálókkal hozható összefüggésbe.

Eredményünk szerint a külföldiek tudatosan választanak maguknak lakóhelyet, mégpedig nagy valószínüség szerint azokban a kistérségekben, ahol honfitársaik már nagyobb számban letelepedtek, segítve öket a vándorlás folyamatában, beilleszkedésben, adminisztratív kötelezettségek megoldásában, munkahely keresésében, lakhatás kérdésében. Természetesen itt nem egy statikus helyzetről van szó, hiszen a külföldiek nem 100\%-osan e szerint a rendszer szerint választanak új lakóhelyet, továbbá belföldi vándorlásaik is módosíthatják a struktúrát. Így azt állapíthatjuk meg, 
hogy a szoros kapcsolatok mellett diffúz módon a külföldiek kis távolságú lakóhelyváltoztatásának lassú folyamataként nyugati irányba tolódik el súlypontjuk.

\section{Helyzetpotenciál mutató}

Ezt az eredményt felhasználva azt tudjuk mondani, hogy az adott külföldi állampolgár számára az ugyanolyan állampolgárságú Magyarországon élő honfitársai jelentenek vonzó célpontot. Így a helyzetpotenciál mutató segítségével képet kaphatunk arról, hogy a különböző állampolgárságú külföldiek hogyan látják hazánk területét, mint potenciális letelepedési célpontokat. A használt elérhetöségi potenciált a Hansen-féle gravitációs modellböl számoltuk (Hansen 1959 - idézi Nemes Nagy 2005). A kutatás során az elérhetőség fogalma mindig fizikai elérhetőséget jelent, ezen belül is elérési időt, percben. A hálózatokon ArcView Network Analyst programozásával a minimális elérési időt igénylő optimális útvonalak időigényét állapítottuk meg az ország kistérségei között.

$\mathrm{Az}$ elérhetö célok tömegeit az egyes kistérségek megfelelő állampolgárságú külföldi népessége alapján állapítottuk meg. Jelen elemzésben figyelembe vettük az adott térségen belüli elérhetőségi viszonyokat is, vagyis a térségen belüli elérhető célokat. A gravitációs modellek közül lineáris modellt alkalmaztunk számitásaink során, így a tér egy i pontjában a potenciál:

$$
P_{i}=\sum_{j \neq i} \frac{B_{j}}{d_{i j}}+\frac{B_{i}}{d_{i}}
$$

ahol $B_{i}, B_{j}$ az elérhetö célok tömegei, $d_{i j}$ az $i$ és $j$ kistérség-központok közötti távolság percben, míg $\mathrm{d}_{\mathrm{i}}$ a saját távolság (percekben), amit úgy számolhatunk ki, hogy az adott kistérség területét körnek tekintve meghatározzuk annak sugarát, melyet arányosnak tekintünk az egyes kistérségeken belüli közúti távolságokkal, és e sugár megtételéhez szükséges időt tekintjük saját távolságnak.

Az ukrán, román, szerb-montenegrói állampolgárok esetén a kiszámolt kistérségi potenciál értékeket térképen ábrázoltuk (4., 5., 6. ábra). 


\section{4. ÁBRA}

Kistérségek elérhetöségi potenciálja ukrán állampolgárokra, 2007. január 1. (Accessiblilty Potential Map by Ukrainian Citizens Residing in Hungary by Subregions, 1 January 2007)

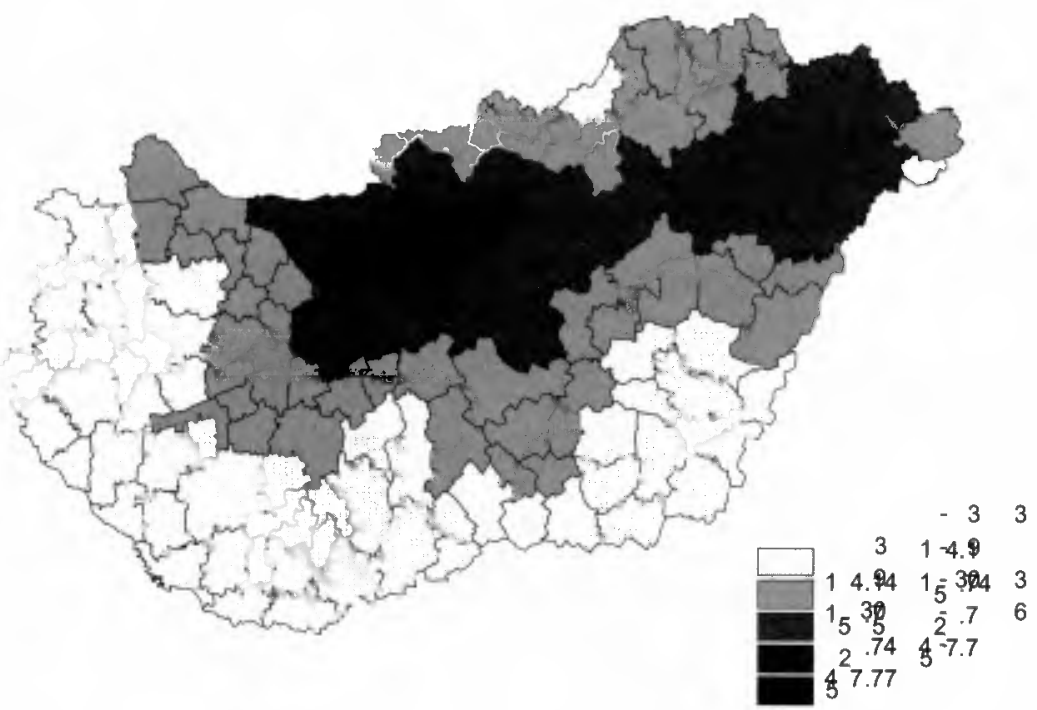

Forrás: Saját szerkesztés.

\section{5. ÁBRA}

Kistérségek elérhetöségi potenciálja román állampolgárokra, 2007. január 1. (Accessiblilty Potential Map by Rumanian Citizens Residing in Hungary by Subregions, 1 January 2007)

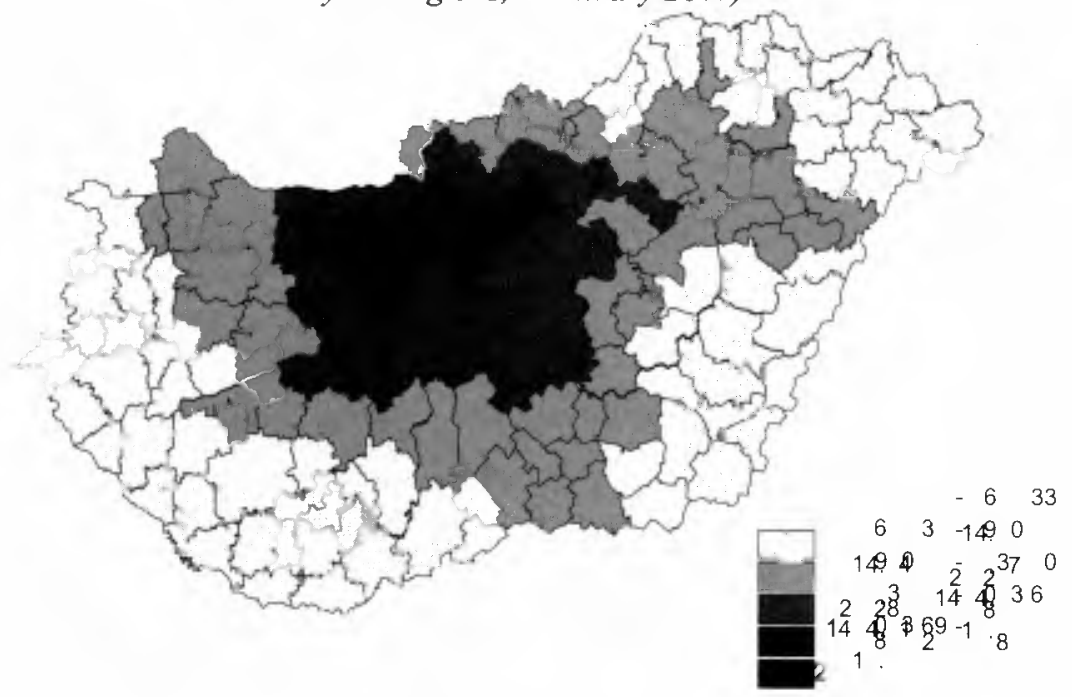

Forrás: Saját szerkesztés. 


\section{6. ÁBRA}

Kistérségek elérhetöségi potenciálja szerb-montenegrói állampolgárokra, 2007. január 1. (Accessiblilty Potential Map by Serbian and Montenegrin Citizens Residing in Hungary by Subregions, 1 January 2007)

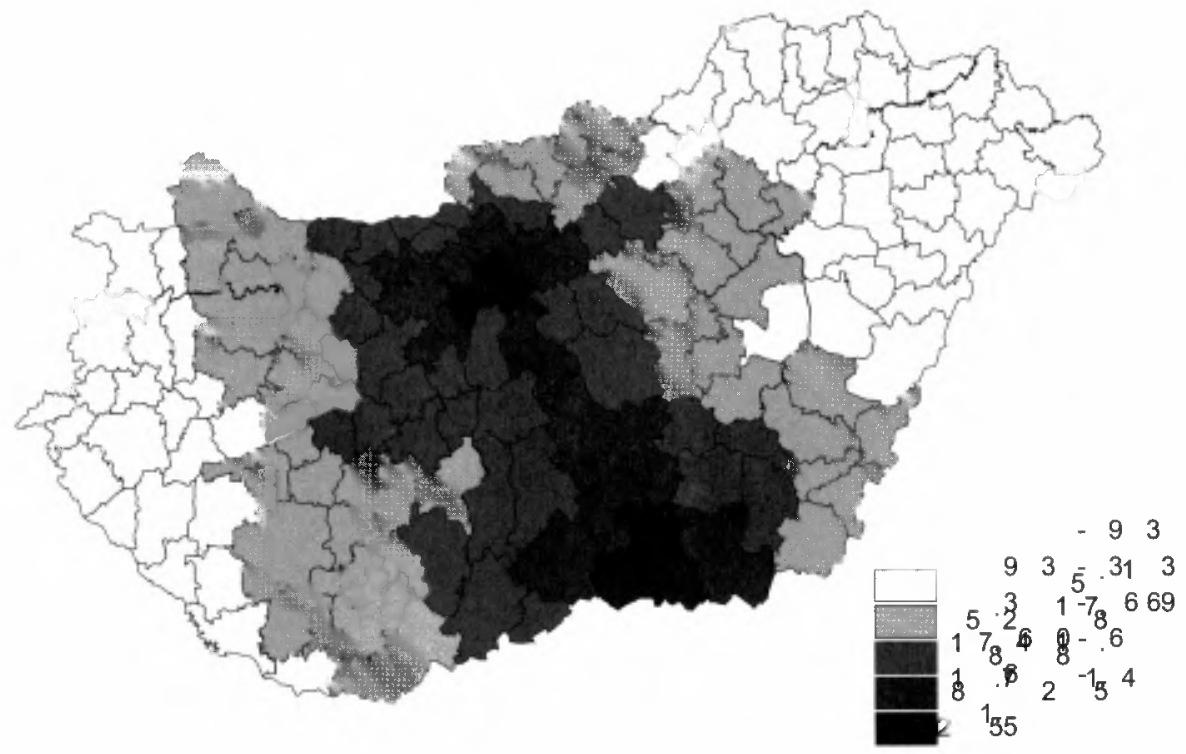

Forrás: Saját szerkesztés.

A térképekröl leolvasható, hogy más-más a Magyarországon tartózkodó külföldi állampolgárok esetén a kistérségek helyzetpotenciál eloszlása. A küldö országok és Budapest közötti „csatornákat” fedezhetünk fel az ukránok és a szerbmontenegróiak esetén, míg a románok számára leginkább csak Budapest környéke jelent vonzást. Az ukránok kelet-nyugat irányú, míg a szerbek esetén dél-északi erős potenciál-folyosókat tapasztalhatunk, a románoknál pedig leginkább a teljes magyarországi lakónépességre jellemző Budapest körüli centrális erőteret.

\section{Összefoglalás}

A tanulmányban sikerült igazolni, hogy a jövedelem-különbségek mellett a kistérségek elhelyezkedése, helyzete, központi vagy éppen határ menti jellege, valamint a korábban érkezettek területi megoszlása befolyásolja a külföldiek magyarországi elhelyezkedését.

A Balaton vidéke föként természetföldrajzi, turisztikai értékeinek köszönheti a külföldiek magasabb érdeklődését. Budapest környékét, mint dinamikus centrumtérséget széles állampolgársági, foglalkozások szerinti megoszlás jellemzi. Sok az aktív korú és a magas iskolai végzettségü a külföldiek között. Azaz a képzett, ma- 
gasan kvalifikált munkaerỏt ez a centrum nagyobb távolságokról is képes mozgósítani. A határ menti térségek esetén a magasabb iskolai végzettségūek, az aktív korúak és a foglalkoztatottak aránya kisebb a centrum területekénél, de a hazai átlagnál mindenképpen magasabb. E térségekben az állampolgárság és a foglalkozási föcsoportok szerint is erősen koncentrálódik a külföldi népesség. Azt mondhatjuk, hogy a külföldiek az érkezésükkori letelepedési helyüket nemigen változtatják jelentős mértékben nagyobb távolságú költözésekkel. A letelepedett külföldiek másmás preferencia alapján választanak lakóhelyet, melyet legfeljebb kistérségeken belüli mozgásokkal változtatnak. A fenti centrum-határ kistérség-csoportok között nincs intenzív áramlás.

Megfigyelhetỏ az állampolgársági vizsgálatok esetén, hogy az újonnan érkezők a már letelepedettek területi struktúrája szerint oszlanak meg. Eredményünk szerint a külföldiek tudatosan választanak maguknak lakóhelyet, mégpedig nagy valószínúség szerint azokban a kistérségekben, ahol honfitársaik már nagyobb számban letelepedtek, segítve az új érkezőket a beilleszkedésben.

Végül a helyzetpotenciál mutató segítségével kísérletet tettünk arra, hogy megmutassuk, a román, ukrán és szerb-montenegrói állampolgárok hogyan láthatják hazánk kistérségeit, mint potenciális letelepedési célpontokat, ahol elsősorban a migrációs hálózatok játszanak domináns szerepet.

\section{Irodalom}

Hablicsek L. (2003) Magyarország népességének jövőbeli alakulása. Kutatási jelentések 68. KSH Népességkutató Intézet, Budapest.

Hatton, T.J.-Williamson, J.G. (2005) Global Migration and the World Economy: Two Centuries of Policy and Performance, Mass. MIT Press, Cambridge.

Illés S.-Lukács É. (2002) A személyek szabad áramlásának statisztikai szempontú vizsgálata. - Migróció és statisztika. Kutatási jelentések 71. KSH NKI, Budapest. 13-51, o.

Massey, D.S-Taylor, J. E. (2004) International Migration: Prospects and Policies in a Global Market. Oxford University Press, Oxford.

Michalkó G.-Illés S. (2003) A turizmus és a migráció néhány összefưggése. - Demográfia. 4. 352-374. o.

Nemes Nagy J. (szerk.) (2005) Regionális elemzési módszerek. Regionális Tudományi Tanulmányok 11. ELTE Regionális Földrajz Tanszék - MTA ELTE Regionális Tudományi Kutatócsoport, Budapest.

Rédei M. (2002) Nemzetközi migráció. - Bemek Á. (szerk.) A globális világ politikai földrajza. NTK, Budapest. 356-385. o.

Rédei M. (2007) Mozgásban a világ, a nemzetközi migráció földrajza. Eötvös Kiadó, Budapest

Sik E. (1999) Migrációs potenciál a mai Magyarországon. - Európai Tükör. A munkaeró migrációja és az Európai Unió. 61. 93-118. o. 